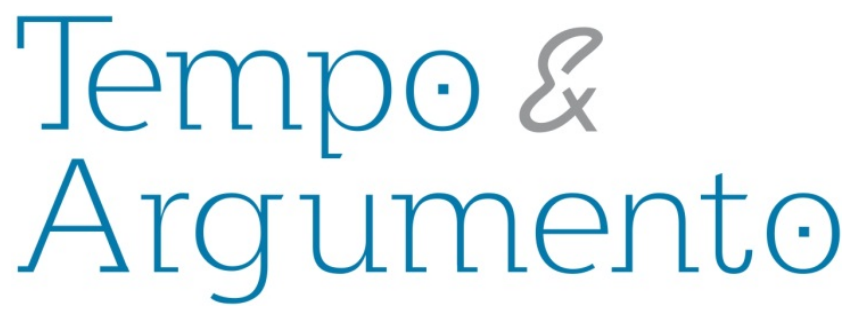

\title{
"O que era simples imprensa virou mídia": como o MST divulgou os meios de comunicação de massa
}

\begin{abstract}
Resumo
Este artigo analisa a construção de uma agenda política do Movimento dos Trabalhadores Rurais Sem Terra (MST) que tratou do lugar ocupado pelos meios de comunicação de massa nas reivindicações de movimentos sociais nas décadas de 1980 e 1990. Os impressos estudados foram o Boletim Sem Terra, o Jornal Sem Terra e a Revista Sem Terra, materiais de divulgação que constituíram um campo de comunicação em defesa de projetos políticos afinados à reforma agrária no Brasil. As produções, distribuições e usos dos impressos para capacitar quadros e divulgar a organização do MST tiveram o apoio de entidades civis, intelectuais, jornalistas, sindicalistas e lideranças sem-terra. Dentre uma variedade de temas publicados, o presente texto delimita editoriais, reportagens e artigos que expressaram posições da direção nacional do MST diante do silenciamento ou de coberturas dadas por empresas de televisão, rádio e jornais de ampla circulação às mobilizações de trabalhadores rurais sem-terra.
\end{abstract}

Palavras-chave: Movimento dos Trabalhadores Rurais Sem Terra. Meios de Comunicação de Massa. Impressos.

\section{Fernando Perli}

Doutor em História pela Universidade Estadual Paulista (UNESP/Assis). Pós-Doutorando em História Social pela Universidade Federal do Rio de Janeiro (UFRJ). Bolsista de Pós-Doutorado Sênior do CNPq. Professor do Programa de PósGraduação em História da Universidade Federal da Grande Dourados (UFGD)

Dourados, Mato Grosso do Sul - BRASIL fernandoperli@ufgd.edu.br

\section{Para citar este artigo:}

PERLI, Fernando. "O que era simples imprensa virou mídia": como o MST divulgou os meios de comunicação de massa. Revista Tempo e Argumento, Florianópolis, v. 9, n. 21, p. 181 - 209. maio/ago. 2017.

DOI: $10.5965 / 2175180309212017181$

http://dx.doi.org/10.5965/2175180309212017181 


\title{
"What was simple press turned into media": how Brazilian MST spread mass media
}

\begin{abstract}
This article analyzes the construction of a political agenda of the Brazilian Landless Workers' Movement (MST) which dealt with the place occupied by the mass media in the demands of social movements in the 1980 s and 1990s. The material studied comprises the Boletim Sem Terra, the Jornal Sem Terra e the Revista Sem Terra, all of which constituted a field of communication in defense of political projects in tune with the agrarian reform in Brazil.The production, distribution and use of the printed material to train cadres and publicize the MST organization were supported by civil society, intellectuals, journalists, trade unionists and landless leaders. From a variety of published themes, the present text delimits editorials, articles and opinion columns that expressed positions of MST national leadership before the coverages or the silencing by mainstream television, radio and newspapers concerning the mobilizations of landless rural workers.
\end{abstract}

Keywords: Brazilian Landless Workers' Movement. Mass Media. Press.

\section{Introdução}

Em matéria publicada pelo Jornal Sem Terra (JST) no início do século XXI, Vito Gianotti, então coordenador do Núcleo Piratininga de Comunicação (NPC) e reconhecido militante da comunicação sindical, popular e comunitária, abordou as ações da mídia que atingiam a questão da terra e da reforma agrária. Ao percorrer os caminhos da história, o jornalista defendeu que os movimentos sociais deveriam perder as ilusões com os grandes meios de comunicação e fortalecer suas próprias mídias. Dos velhos jornais e livros raros ao rádio, televisão e internet, “o que era simples imprensa virou mídia” (JST, 2006, $n^{\circ} 262$, p. 3), uma denominação complexa que exigia dos movimentos sociais novas táticas e estratégias para combater forças hegemônicas. 
A partir de uma perspectiva construída ao longo da formação do Movimento dos Trabalhadores Rurais Sem Terra (MST), mais especificamente nas décadas de 1980 e 1990, as concepções de imprensa, meios de comunicação de massa e mídia circularam na militância e foram definidas como um conjunto de impressos, meios televisivos e radiofônicos com finalidades econômicas e comerciais que não correspondiam, em suas linhas editoriais, aos anseios políticos do movimento social.

Entre os historiadores, o uso da mídia como fonte histórica em pesquisas que trataram de movimentos sociais fez crescer o problema da notícia e das posições de empresas jornalísticas na produção histórica e na memória social. Nas últimas décadas, estudos sobre o MST demonstraram a variedade de abordagens que lidam com o contemporâneo e o tempo presente. Muitas dessas pesquisas suscitaram questões metodológicas, nem sempre vislumbradas nos textos publicados, para lidar com a tensa relação entre MST e meios de comunicação de massa.

Este artigo, em sentido inverso ao que muitos trabalhos ponderaram sobre a produção e veiculação de notícias em meios de ampla circulação sobre os trabalhadores rurais sem-terra, propõe perscrutar as posições assumidas pelo MST sobre os meios de comunicação de massa através de impressos produzidos pelo movimento social. $\mathrm{Na}$ intenção de contribuir para esta discussão, o texto tem como proposta analisar o Boletim Sem Terra (BST), o Jornal Sem Terra (JST) e a Revista Sem Terra (RST). Embora entenda a importância de investir na história das mídias do MST, o objetivo é se debruçar sobre os conteúdos dos impressos. Num sentido geral, estes impressos foram produzidos para formar a militância e dar visibilidade à luta social num processo de associação de diferentes entidades civis de apoio aos trabalhadores rurais sem-terra.

As dificuldades de veiculação das reivindicações dos sem-terra em canais de comunicação locais, regionais e nacionais criaram condições políticas no MST para a elaboração e apropriação de meios de comunicação com estatutos diversos. Muitos, produzidos num campo específico de comunicação que divulgou posições do MST sobre a mídia, tornaram-se fontes importantes para a compreensão da história dos trabalhadores rurais sem-terra. 
Parte-se do pressuposto de que um combate de significações entre o MST e a imprensa de ampla circulação tornou-se fio condutor de uma política de comunicação projetada pelo movimento social. A construção de estratégias de divulgação da luta para responder à invisibilidade dos trabalhadores rurais sem-terra no campo midiático definiu uma política de comunicação do MST que orientou militantes para compreender o papel da comunicação na sociedade de classes. A produção de meios de comunicação do MST tornou-se uma ação política contra a mídia tradicional e os sentidos de violência e desordem dados aos sem-terra.

Entendidos como espaços de tensões e de luta simbólica, os meios de comunicação são instrumentos de difusão de representações de grupos políticos que configuram, demarcam e colocam em disputa diferentes projetos de sociedade (BACZKO, 1984). Legitimações de projetos elaborados num campo de concorrências em que se produzem e difundem notícias e representações no campo social são determinadas pelos interesses de grupos que forjam percepções do social que não são neutras, expressando uma luta de representações (CHARTIER, 2002, p. 47).

Uma luta por se fazer reconhecer perfaz a trajetória de organização dos meios de comunicação de massa. A função de jornais de ampla circulação, da radiodifusão e da televisão transmutou a ideia de política e de nação na cotidianidade. Desviada ao longo dos anos pelo dispositivo econômico que se apoderou dos meios, a função adquiriu sentido mercadológico e consumista em que pobres sonham o mesmo sonho que os ricos num processo de massificação que luta pela transnacionalização e homogeneização das culturas (MARTIN-BARBERO, 2015, p. 234).

Nesse contexto, movimentos sociais passaram a organizar seus meios de comunicação para defender projetos diante de uma tendência de uniformização de ideias, exclusão e marginalização de grupos sociais que se opuseram aos interesses privados que alcançaram a educação e a cultura. Assim, na formação, consolidação e internacionalização do MST, duas frentes de atuação política se cristalizaram no campo da comunicação. Uma, organizou meios de comunicação para a militância, tendo como pressuposto a ocupação de espaços e a visibilidade social para despertar o interesse da classe política e da sociedade civil pelo tema da reforma agrária no Brasil. Outra assumiu 
inúmeros movimentos sociais em defesa de um projeto de democratização da mídia no final da década de 1990.

A disputa entre grupos sociais e políticos pela opinião pública instigou-nos a examinar um extenso material publicado por entidades solidárias, pelo próprio MST e por diversos profissionais que, ao realizarem projetos de comunicação alternativos, tiveram seus trabalhos reconhecidos nos círculos da militância sem-terra. Num sentido geral, em meio a uma variedade de trabalhos sobre o MST, este texto propõe entender debates e estratégias de comunicação que circularam e contribuíram para a organização dos semterra.

\section{O movimento social e a imprensa}

A formação do MST no início da década de 1980 esteve fortemente vinculada à conquista de apoio de entidades e de setores da sociedade civil. Para alcançar este objetivo, as articulações políticas entre movimentos sociais de luta pela terra dependeram de estratégias de comunicação. Entidades sociais, religiosas e partidárias contribuíram para a delimitação de um campo de comunicação dinâmico numa campanha de solidariedade aos trabalhadores rurais que montaram acampamentos nos estados do Rio Grande do Sul, Santa Catarina, Paraná, São Paulo e Mato Grosso do Sul.

Um dos principais materiais de comunicação que serviu para identificar lideranças rurais, sindicais, religiosas, civis e apoiadores da luta pela terra nestes estados foi o Boletim Sem Terra. Entre 1981 e 1984, o informativo da campanha de solidariedade aos agricultores acampados da Encruzilhada Natalino de Ronda Alta (RS) foi produzido por entidades de apoio, como a Comissão Pastoral da Terra (CPT), o Movimento de Justiça e dos Direitos Humanos (MJDH), a Pastoral Universitária (PU), o Conselho Nacional de Igrejas Cristãs (CONIC) e o Centro de Assessoramento Multiprofissional (CAMP), que tinham como referência a cidade de Porto Alegre (RS). 
O boletim tornou-se um "espaço de sociabilidade" (SIRINELLI, 1996, p. 248) que aproximou forças políticas e agricultores de diversas regiões do Brasil através da divulgação de cartas de apoio de representantes de sindicatos rurais, entidades civis e religiosas, trabalhadores e opinadores que se posicionaram a favor dos acampados e contra a ditadura militar. Agricultores, religiosos e produtores do boletim, alegando que a imprensa produzia uma imagem negativa dos trabalhadores rurais sem-terra, alertaram sobre as dificuldades encontradas para permanecerem na terra e as incompatibilidades vivenciadas por camponeses para ingressarem no mercado de trabalho urbano. Por meio do embate político, na construção da notícia, cresceu a rede de solidariedade aos acampados e a divulgação de lutas similares que alcançaram o Espírito Santo e a Bahia.

Embora a rede de solidariedade aos acampados da Encruzilhada Natalino divulgada no Boletim Sem Terra tenha crescido, o que ganhou espaço nos meios de comunicação comerciais e de ampla circulação foram as dissensões entre o poder público e os agricultores. No início da década de 1980, um dos motivos dos embates foi o relatório apresentado pela Fundação Sul-rio-grandense de Assistência (FUNDASUL), órgão da Secretaria do Trabalho e Ação Social do Governo do Estado do Rio Grande do Sul, sobre os antecedentes e a situação socioeconômica dos agricultores da Encruzilhada Natalino. O relatório apresentado pelo Governo do Estado descontentou agricultores e agentes de apoio que o definiram como injusto e preconceituoso.

A intensificação das desavenças teve como causa o pronunciamento de Adalberto Prates, secretário substituto do Trabalho e da Ação Social do Governo do Estado do Rio Grande do Sul. Numa ampla divulgação na imprensa gaúcha, dados apontados pelo relatório foram defendidos pelo secretário, que afirmou existirem 43 colonos acampados que possuíam propriedades rurais e outros bens, situação que os fazia não merecer "a terra, pois eram aventureiros e aproveitadores". Além disso, o relatório enumerou 16 agricultores que "tiveram envolvimento em ocorrências policiais" (BST, 1981, n 4, p. 5).

As informações do relatório difundidas pela imprensa produziram um efeito de criminalização dos trabalhadores rurais sem-terra envolvidos nas reivindicações. Diante do cenário, o Boletim Sem Terra denunciou políticos, fazendeiros, imprensa e o regime militar pela falta de liberdade de expressão. As explicações criteriosas contidas no 

legal no campo, o combate da linguagem com a imprensa (BERTOL, 2003, p. 7).

A organização do Boletim Sem Terra adquiriu um caráter coletivo ao ser assumida pelo Comitê de Apoio aos agricultores sem-terra do centro-sul e, posteriormente, pelo Centro de Assessoria Multiprofissional (CAMP), fundado em 1983 por estudantes, religiosos e diversos profissionais com inserção orgânica em movimentos sociais, dentre os quais, militantes e jornalistas que contribuíram na elaboração do boletim.

O CAMP foi originado como uma ONG com objetivo de atuar na educação e organização de movimentos populares. Como Centro de Educação Popular, dirigia ações apoiadas por organizações sociais do Brasil e de vários países. Ligado ao sindicalismo combativo gaúcho, o CAMP tinha a finalidade de prestar serviços que incluíam a produção de folhetos e manuais informativos para a sindicalização (BST, 1984, nº 35, p. 3).

No período de articulação entre as lutas pela terra no Rio Grande do Sul e outros estados do centro-sul do Brasil, que resultou, em 1984, na fundação do MST no I Encontro Nacional dos Trabalhadores Rurais Sem Terra, realizado em Cascavel (PR), o CAMP promoveu a transformação do boletim em Jornal Sem Terra. A transição de boletim a tabloidecontou com o controverso serviço de impressão prestado pelo Jornal Zero Hora(ZH). A tecnologia da impressão do jornal e o preço atrativo comparado com os custos apresentados por outras empresas foram decisivos para firmar uma relação comercial que prevaleceu sobre os interesses ideológicos. Embora alguns jornalistas do ZH fossem simpatizantes do movimento de solidariedade aos trabalhadores rurais, isso não se refletia nas notícias que o Zero Hora veiculava sobre os agricultores sem-terra, passíveis de muitas críticas pela militância.

A atuação do ZH na impressão do Jornal Sem Terra tinha implicações, pois o diário gaúcho não se mostrava compreensível com os sem-terra, classificando-os como "foras da lei". Esta relação pouco amistosa entre meio de comunicação e movimento social foi percebida nos enunciados de reportagens que abordaram a luta dos agricultores da Encruzilhada Natalino, preservando o conceito de propriedade privada através do uso do 
Que pesem as posições contrárias do ZH aos sem-terra, as coberturas do jornal deram visibilidade ao movimento social rural. Para a repórter do Zero Hora, Ivone Cassol, em texto publicado pelo Boletim Sem Terra:

Qual teria sido o destino das famílias que se postaram na beira da estrada, formando o acampamento de Encruzilhada Natalino, se os meios de comunicação não as tivessem descoberto e divulgado o movimento? Certamente teria desaparecido da mesma forma que surgiram. (...) A maioria dos jornalistas compreendem a importância e a perspectiva da trajetória de Natalino. (...) O esforço dos jornalistas para que tudo isso chegasse ao grande público foi notável. Tanto que a cobertura de Zero Hora sobre a luta dos sem-terra acabou ganhando o Prêmio Esso de 1981, o troféu mais importante do jornalismo brasileiro. O aspecto a salientar é que a conquista do prêmio de certa forma obrigou o jornal a manter o noticiário sobre a luta dos agricultores sem-terra. (BST, $1983, n^{\circ} 33$, p. 13)

Apesar de a jornalista destacar o engajamento dos agricultores da Encruzilhada Natalino como um exemplo para a resistência dos acampados e o crescimento da rede de solidariedade constituída entre movimentos populares de diferentes estados do Brasil, o que chamou atenção foi a importância atribuída à divulgação da situação dos acampados pelo Zero Hora.

Muitos jornalistas da imprensa escrita, notoriamente contrária à causa dos semterra, passaram a colaborar com impressos do MST, especialmente com o Jornal Sem Terra, quando tiveram contato com acampamentos. Situações deste tipo também podem ser percebidas no texto da repórter do ZH:

À medida que conheciam melhor o acampamento, os repórteres sentiam a falta de alternativas, o modelo fundiário e agrícola empurrando os trabalhadores a uma atitude desesperada de se expor ao relento, às críticas, à zombaria daqueles que não queriam enxergar a realidade. Os jornalistas também foram percebendo os diferentes interesses em jogo, a presença de "aproveitadores", o despreparo de muitos e as contradições de um grupo que se formara espontaneamente, com unidade apenas no objetivo maior: a posse de um pedaço de terra. (BST, $1983, n^{\circ} 33$, p. 13) 
Embora tenha admitido que a imprensa não criara o acampamento, Cassol percebeu uma dimensão política que envolveu jornalistas e editores numa complexa relação com a organização dos trabalhadores rurais. Ao longo da década de 1980, a divulgação dos sem-terra na imprensa, num primeiro momento, restringiu-se a jornais de circulação regional e, num segundo, diante do crescimento do MST, caracterizou-se pela demarcação de forças políticas que evidenciaram distâncias e aproximações entre meios de comunicação de massa e movimento social.

A definição de um “campo simbólico" (BOURDIEU, 2001, p.16) dos trabalhadores rurais sem-terra na imprensa de grande circulação ficou evidente com a cobertura de jornais paulistas - como a Folha de S. Paulo, O Estado de S. Paulo e o Jornal da Tarde -, dada aos conflitos pela terra, com destaque para o problema fundiário do Pontal do Paranapanema, a origem do MST e o aumento da violência no campo diante das frustrações de lideranças sem-terra com o Plano Nacional de Reforma Agrária (PNRA). Aos olhos de entidades representativas da classe trabalhadora rural, os resultados obtidos com a aprovação do PNRA demonstraram que a reforma agrária era um assunto menos relevante para a grande imprensa na nascente Nova República. Dívida externa, inflação e incidentes planos econômicos foram os temas mais considerados pela mídia no final da década de 1980 (BERTOL, 2003, p. 11), mantendo-se diversas formas de mobilização de grupos sociais na invisibilidade.

Com frequência, os meios de comunicação de massa construíram um discurso de consenso que sustentou a transição do regime autoritário para o democrático. O poder político construído e exercido através do consenso, além de depender do aparelho de Estado, encontrou na mídia, em especial nas empresas de televisão, importantes instituições que moldaram um processo hegemônico (PORTO, 2007, p. 110). Em meio a controvérsias teóricas que apontam o conceito de hegemonia como apropriado de maneira diversa e superficial (WILLIAM, 2016), o que nos ocupa neste momento é sua configuração, dependente de uma construção consensual definida por temas e valores que não reconhecem controvérsias num manto de objetividade e imparcialidade. $O$ campo de comunicação hegemônico, ao compactuar com o Estado a transição de regimes políticos na década de 1980, definiu posições políticas aceitáveis e marginalizou 

pela televisão e por jornais de ampla circulação. O silêncio produziu críticas por parte de apoiadores do MST, que via a imprensa como parcial e superficial quando tratava das condições e demandas sociais de trabalhadores rurais sem-terra. Assim, além das estratégias de produção de seus meios de comunicação, o MST organizou ações políticas para chamar atenção da imprensa e da sociedade civil.

Dentre as principais ações para despertar discussões e dialogar com a classe política e agentes públicos sobre a questão agrária (Berger, 1998: 27) estavam as ocupações e as manifestações de rua, aos poucos denominadas de marchas, que tinham como um dos objetivos fortalecer "valores, padrões de comportamento" (HOBSBAWM; RANGER, 1997, p. 17) e dar visibilidade ao MST no espaço público.

Além disso, foram produzidos meios de divulgação para um público mais amplo, como programas de rádio, matérias publicitárias para televisão e outdoors patrocinados por entidades solidárias. Vale mencionar que as poucas inserções dos trabalhadores rurais sem-terra em programas televisivos ou de rádio estiveram vinculadas a notícias de ocupação de terra e de confronto entre agricultores e polícia em situação de desocupação. A alternativa para contrapor um discurso que associava o MST à violência foi a produção de audiovisuais. Com o respaldo de entidades solidárias conhecidas pela defesa dos direitos humanos ou pelas experiências no ramo das comunicações, como o Instituto Sedes Sapientiae, o Centro Santo Dias dos Direitos Humanos, a Central Única dos Trabalhadores (CUT) e o Jornal Sem Terra, em 1985 foi produzido um audiovisual que, a duras penas, foi exibido nos horários comerciais das principais redes de televisão do Brasil, em saudação ao Dia do Trabalhador Rural comemorado pelas entidades do movimento sindical no dia 25 de julho.

As dificuldades de exibição da homenagem nas grandes redes de comunicação geraram indignação da direção nacional do MST veiculada pelo Jornal Sem Terra: 
Com a assinatura das principais entidades do movimento sindical e popular, esses poucos segundos têm uma história. O Departamento Comercial da TV Globo, em São Paulo, não quis a responsabilidade de aceitar o anúncio. Nem o do Rio. Foram consultar diretamente Roberto Marinho que estava em Brasília e queria ver a mensagem para decidir. Burocracia total. Depois que passou na Globo, foi fácil passar na Manchete e na TVS. Isto que é liberdade de informação. (JST, 1985, $\mathrm{n}^{\circ} 55$, p. 16)

O informe passou por um breve instante nas telas da televisão, mostrando o problema agrário no país e suas relações com a desigualdade social e os conflitos no campo. O tom de denúncia demonstrou a tensa relação entre o MST e empresas de comunicação caracterizada pelo crescente debate sobre o lugar político dos meios radiofônicos e televisivos na luta pela reforma agrária. Em 1987, o repórter francês Olivier Colombani, conhecido nos círculos da militância por trabalhos de enfoques sociais que repercutiram na Europa, estudou a luta dos sem-terra no Brasil e denunciou que rádios porta-vozes dos interesses dos latifundiários, a desinformação na imprensa escrita e o sensacionalismo ao vivo nas TVs eram para o MST "um trabalho tão difícil quanto a conquista de uma terra para viver" (BERTOL, 2003, p.11).

Diante das barreiras criadas, o MST manteve relações com rádios locais ou de ampla circulação. Foi o caso, em 1987, do Programa dos Trabalhadores Rurais Sem Terra transmitido pela Rádio AM Aparecida em parceria com o MST. A repercussão nacional dada ao programa reforçou o perfil da emissora, conhecida pelas posições contrárias ao regime militar. Diante da abertura política, a rádio notabilizou-se por coberturas de enfoque social. Com o programa no ar, muitos trabalhadores rurais e urbanos puderam ouvir notícias e histórias sobre os sem-terra. A difusão colocou em pauta para os ouvintes a desigualdade da distribuição de terras no Brasil. O projeto teve relevância social em meio a forte influência da Igreja Católica na organização de movimentos sociais do campo.

Em contrassenso ao efervescente clima de "mobilização de massas" que marcou o MST nos anos de 1987 e 1988, a indiferença dos jornais de circulação nacional e das redes de televisão demonstrou para lideranças sem-terra o abismo do direito à comunicação no Brasil. 
Questões como estas, para Hamilton Pereira - então Secretário Agrário do Partido dos Trabalhadores (PT) e conhecido no MST pelo pseudônimo Pedro Tierra em poemas que trataram da luta dos sem-terra - lançaram luz no movimento social sobre os problemas das mediações sociais e políticas na sociedade brasileira. Como então se autodefinia, o "militante informal do MST" entendia que os movimentos sociais eram tratados com pesos diferentes devido à influência da grande imprensa na vida política nacional (TEORIA E DEBATE, 1992, n 18). Seus argumentos partiam do princípio de que quando emergiam lutas políticas institucionais pela reforma agrária, criando-se um clima de debates nas esferas do poder, a cobertura dada pelos meios de comunicação de massa era muito mais intensa, enquanto que o protagonismo de movimentos sociais na luta pela terra, quando rompia as barreiras do silêncio era tratado de maneira tímida e por um viés que retratava a desordem social. Um dos exemplos foi a ampla cobertura dada ao Plano Nacional de Reforma Agrária (PNRA) e a discussão política travada na Assembleia Constituinte sobre os "fins da desapropriação", reduzida ao fluído conceito de "terras improdutivas" (SILVA, 1989, p.171), e a indiferença às mobilizações dos sem-terra.

A partir do III Encontro Nacional do MST, realizado na cidade de Piracicaba (SP) em janeiro de 1987, um rico debate entre lideranças sem-terra e representantes de entidades solidárias à luta pela reforma agrária incluiu na pauta o papel político da imprensa nas mobilizações dos trabalhadores rurais.

Durante os cinco dias de encontro, que contaram com a participação de 200 lavradores de 18 estados, repórteres do Jornal Sem Terra organizaram debates sobre "Igreja, sindicalismo, eleições, mulheres, assentamentos e violência". Os jornalistas Isaac Akcelrud, Flademir Araújo e Cácia Cortez coordenaram os debates que tinham como proposta "monopolizar a palavra pelos lavradores" (JST, 1987, n 61, p. 4). Como resultado, mais de dez horas de gravação das conversas em torno dos problemas enfrentados pelos trabalhadores rurais serviram para publicar um extenso material informativo que deu bases para as estratégias de luta dos próximos anos.

A mesa redonda que tratou da "violência no campo", composta por lideranças como João Rodrigues, Luiz Soares, Isaias Vedovatto, José Rainha Júnior, Zelito Moreira e o assessor dos sem-terra Carlos Massolo, chamou atenção por debater os inimigos do 
Na opinião destas lideranças, as relações de poder firmadas entre os inimigos do MST demonstravam o sentido conservador da Nova República por tratar de maneira desigual os sujeitos sociais e políticos envolvidos na questão agrária. Para Isaias Vedovatto, a imprensa demonstrava um posicionamento tendencioso ao valorizar as entidades representativas da classe ruralista em detrimento da organização dos trabalhadores rurais. Um dos motivos das críticas não eram os meios de comunicação de abrangência nacional, mas as rádios e jornais locais e regionais que apresentavam um quadro de ataque ou de indiferença diante da luta dos sem-terra e retratavam posições e vínculos de seus proprietários com políticos, geralmente, ligados a partidos que agregavam forças aos setores conservadores que defendiam a estrutura fundiária.

Em sua fala transcrita pelo Jornal Sem Terra, Vedovatto afirmou que:

A imprensa sabe denunciar a invasão da terra. Mas quando foram espancados mais de 50 camponeses e nós conseguimos laudo médico, provando, isso quase não foi divulgado. Por mais documentada que fosse a denúncia, só saiam umas poucas linhas. Mas os ataques e calúnias contra nós ocupavam páginas inteiras. (JST, 1987, $\mathrm{n}^{\circ} 61, \mathrm{p} .4$ )

O silêncio da imprensa também foi percebido por lideranças sem-terra e militantes petistas em manifestações massivas dos trabalhadores rurais, como na Caravana à Brasília (DF), organizada em outubro de 1987. Composta por agentes de apoio, trabalhadores rurais, simpatizantes e representantes de entidades solidárias, o manifesto reuniu cerca de 6000 participantes. A organização da grande Caravana dependeu da articulação entre lideranças sem-terra e entidades solidárias de diversos estados, tendo à frente o MST, o PT e a CUT.

Para desagrado dos organizadores, a cobertura dada pela televisão restringiu-se ao breve momento da audiência que lideranças tiveram com o presidente do Congresso Constituinte, deputado Ulysses Guimarães (JST, 1987, n 67, p. 9-13). Anos depois, em referência à“insignificante cobertura dada pela imprensa” à Caravana, Hamilton Pereira recorreu ao romance "Garabombo, o invisível”, do escritor peruano Manuel Scorza: 
(...) compreendemos o significado mais profundo do que o peruano Manuel Scorza nos conta em seu livro 'Garabombo, o invisível'. Como os índios peruanos, os camponeses brasileiros são invisíveis para a sociedade dos 'patrícios'. Milhares de lavradores acamparam na capital da República e alcançaram o benefício dos holofotes das emissoras de TV no breve momento da audiência com o deputado Ulysses Guimarães. $O$ resto foi um estrondoso silêncio. (TEORIA E DEBATE, 1992, $\mathrm{n}^{\circ}$ 18)

O desalento de Pereira atingiu o lugar político dos meios de comunicação de massa na sociedade brasileira, marcado por um campo jornalístico unilateral, que tratava de forma desigual as lutas cotidianas pela terra e o jogo de poder institucional em torno da reforma agrária. Assim, para o autor, a sociedade não se movia a favor da insurgência dos excluídos devido a pouca visibilidade dada por empresas de televisão, rádios e jornais às mobilizações de trabalhadores rurais sem-terra (TEORIA E DEBATE, 1992, $n^{\circ} 18$ ). O MST posicionou-se ante o silêncio e àparcialidade da imprensa, que deveria ter como resposta a eficiência da organização dos sem-terra através de novas técnicas de comunicação e construção de práticas de leitura que demonstrassem os interesses políticos e econômicos por detrás das notícias.

\section{O movimento social e a visibilidade na mídia}

Na década de 1990, o MST ampliou seus meios de comunicação através do uso de outras tecnologias, como as visuais, fonográficas, rádio difusoras e virtuais. Não sendo um fenômeno apenas do MST, outros movimentos sociais produziram mídias alternativas para divulgarem notícias, projetos políticos, registrarem experiências e lançarem representações que compuseram quadros de identificação entre militantes e simpatizantes. Este crescimento, de maneira geral, fez parte de um contexto de conquistas de direitos, de afirmação e visibilidade de atores coletivos resultantes da aceleração dos processos de fragmentação cultural e do aumento do pluralismo social (CORREIA, 2007, p. 54).

No MST, tais mudanças desenvolveram-se em fronteiras complexas entre o espaço público e o espaço de visibilidade midiática. A luta por um aprofundamento democrático exigia uma percepção de que nem todas as mobilizações em espaços públicos eram 

comunicação do MST, como também, compreender as inúmeras formas de circulação e recepção de notícias sobre o MST produzidas pela grande mídia.

Assim, a conciliação entre estratégias de comunicação interna e a exposição de ideias do MST num cenário social fizeram emergir uma política que estabeleceu um conjunto de normas e procedimentos visando consolidar a identidade sem-terra (BERGER, 1998, p.111). Para manter sua identidade sem desmerecer a importância de outras frentes de luta, além de estabelecer parâmetros internos para um campo de comunicação, o MST apoiou diversos movimentos em defesa da democratização da mídia.

Militantes do campo de comunicação e lideranças sem-terra se debruçaram sobre estas questões. Como resultado, em 1995, um documento interno de nove páginas denominado "Por uma política de comunicação do MST", estabeleceu a sujeição das estratégias de comunicação às diretrizes da direção nacional. Assim, sugeriu-se a criação de um coletivo para dar andamento às propostas, através da divisão de tarefas e da garantia de que um núcleo de dirigentes estaria buscando conhecimento na área da comunicação. Esta demanda ficou evidente no item "relacionamento com os meios de comunicação", que defendeu a capacitação de lideranças sem-terra para lidar com a imprensa, mantendo contatos com jornalistas e elaborando materiais de uso interno (MST, 1995, p. 4-9).

O documento fortaleceu a presença de lideranças sem-terra no campo jornalístico e possibilitou uma maior atenção do MST em relação às posições políticas dos meios de comunicação de massa. Um exemplo de aproximação entre o movimento social e espaços que representavam interesses da grande mídia decorreu do massacre de Eldorado dos Carajás, ocorrido no sul do estado do Pará, em 1996, quando dezenove trabalhadores rurais acampados na Fazenda Macaxeira foram mortos pela polícia militar numa marcha em protesto à demora da desapropriação de terra. 
Em decorrência do massacre, no mesmo ano, o MST enviou carta ao $27^{\circ}$ Congresso Nacional de Jornalistas, realizado em Porto Alegre (RS), posicionando-se frente à influência da mídia na construção da opinião pública. Representada por Gilmar Mauro, a direção nacional do MST agradeceu a repórter Marisa Romão e o cinegrafista Oswaldo Araújo, da TV Liberal - afiliada da Rede Globo no estado do Pará -, por filmarem o massacre e inibirem uma ação militar que poderia levar a uma tragédia de proporções maiores. Em "Carta aos Companheiros Jornalistas e Fotógrafos", o trabalho da imprensa foi lembrado por não deixar o massacre passar "despercebido pela sociedade" (MST, 1996).

Além de emblemático na história do MST pelas referências que se fazem sobre o massacre de Eldorado dos Carajás, o ano de 1996 marcou-se por uma situação inusitada dada ao problema fundiário pela Rede Globo de Televisão através da novela O Rei do Gado. A abordagem da luta dos sem-terra, sua relação com os latifundiários e a classe política foi pauta de textos e entrevistas de intelectuais, jornalistas e cineastas no Jornal Sem Terra. Nas páginas do impresso, em seção Especial, coube uma entrevista com o escritor Benedito Ruy Barbosa concedida à jornalista Débora Lerrer e ao pesquisador e professor Bernardo Mançano Fernandes. O autor da novela foi considerado "um homem apaixonado pela terra" que adicionou na "TV mais poderosa do país, por um ângulo nunca visto antes", o trabalhador rural sem-terra, personagem ausente nas ficções da televisão brasileira. Ao ser questionado sobre a recepção da novela pelo público, o escritor demonstrou muito daquilo que era o lugar da Rede Globo no cenário político da luta pela terra, quando tratou da importância dos números da audiência que faziam da novela “um negócio fantástico" (JST, 1996, n 160, p. 11).

Observações como essas atestam que as narrativas produzidas pelos meios de comunicação de massa resultam de sua interação com eventos e protagonistas que constituem a matéria-prima e das expectativas que se criam em torno da audiência, cujo enquadramento e fidelidade ao que se idealiza como público são vitais (ALDÉ, 2004, p. 47). Na sintonia estabelecida com a audiência, a televisão reforçou elementos dominantes da cultura de mercado, demonstrando que a retórica da função social dos meios de comunicação de massa se concentrou nas mãos de interesses privados em que 
A veiculação dos sem-terra em telenovela com grande audiência, embora entendida como uma conquista para o MST, não diminuiu as críticas feitas pelo movimento social às posições da Rede Globo frente à reforma agrária. Em artigo publicado na seção Cultura, o cineasta Renato Tapajós, conhecido por ser preso político e autor do livro "Em câmara lenta”, que denunciou práticas de torturas no regime civilmilitar, tratou diretamente da "maleabilidade ideológica" da Globo ao questionar as intenções de inclusão dos sem-terra na novela. Para o cineasta:

Ao contrário de outros veículos da imprensa (Estadão, por exemplo) que se aferram a uma coerência conservadora que os transforma em monumentos do imobilismo, a Rede Globo dispõe de uma certa flexibilidade em suas posições, permitindo que, em alguns momentos, pareça assumir uma postura progressista. (...) Pode parecer um jogo oportunista - e, sem dúvida o é -, mas é também a prática de sobrevivência de uma grande corporação. (JST, 1996, n 164, p. 16)

Tapajós, ao desconfiar da perspectiva lançada pela rede de televisão aos semterra, reforçou que a inclusão da luta pela reforma agrária na novela não poderia ser vista de maneira simples, como se a Globo levantasse bandeiras, mas sim, como um indicativo de que setores da sociedade brasileira estavam colocando na pauta política a tensão no campo e inserindo as “massas rurais no mercado” (JST, 1996, n 164, p. 16).

Para a direção nacional do MST, a prática política dos sem-terra imbricava-se ao espaço ocupado na mídia, pois a veiculação de imagens era produto das relações de forças, cada vez mais direcionadas ao combate das linguagens e aos fluxos de informação. O lugar da mídia nos movimentos sociais tornou-se um forte componente na organização do MST. O uso articulado de meios de comunicação do movimento social possibilitou um confronto mais visível com setores tradicionais da mídia e a compreensão de que o monopólio da terra tinha muitas relações como o monopólio da comunicação. 
Sob este prisma, projetos de divulgação da luta visaram outros públicos, além de contribuírem para o debate pela democratização da mídia.Uma das idealizações foi a Revista Sem Terra, publicada a partir de 1997 com uma proposta voltada para um públicoleitor com circularidade acadêmica. Com apoio financeiro da Associação Nacional de Cooperação Agrícola (ANCA), a revista apresentou uma linguagem mais formal e discutiu assuntos como privatizações, neoliberalismo, reforma agrária e mídia. Uma de suas seções foi a Comunicação, com artigos que trataram da tensa relação entre os movimentos sociais e a mídia, a construção de uma imagem negativa do MST pelos meios de comunicação de massa, as manipulações de dados de institutos de pesquisas ligados às redes de comunicação e o crescimento da denominada imprensa de oposição.

A Revista Sem Terra foi planejada para fazer um jornalismo alternativo às revistas comerciais semanais, servindo de modelos para outros projetos editoriais que se alinharam à esquerda brasileira. Seus produtores retrataram posições avessas às imagens e reportagens publicadas pela grande mídia. Defendiam que a democratização do campo jornalístico estava na produção de canais de comunicação populares que criassem espaços simbólicos de luta contrários ao monopólio dos meios de comunicação de massa (PERUZZO, 2002, p. 84).

Em Editorial da edição $\mathrm{n}^{\circ}$ 3, com o título "A batalha da (des) informação", o monopólio de conglomerados de mídia foi retratado pela posição de isolamento em que colocavam o MST quando se aproximavam as eleições:

os principais meios de comunicação do país, como uma orquestra afinada, passam a divulgar 'pesquisas de opinião' em que o MST é reprovado pela população em seus métodos de luta pela transformação da realidade no campo. As posições assumidas pelo movimento são contestadas porque, segundo eles, transcenderam a luta pela reforma agrária, como se fazer política ou simplesmente ter o direito de intervir nos destinos na nação fosse apenas prerrogativa de alguns iluminados. (RST, 1998, n 3, p. 1)

Para lideranças de movimentos sociais era necessário construir um projeto popular que pautasse diferentes proposições para a consolidação da democracia, o que incluía a ampliação de oportunidades de setores populares na comunicação social. Nessa direção, 
Confederação Nacional dos Bispos do Brasil (CNBB) e dirigentes sindicais e partidáriosque estabeleceu como um de seus objetivos a democratização da mídia.

Como consenso entre os participantes do Consulta Popular, as políticas econômicas neoliberais levaram o país para um modelo de desenvolvimento subordinado aos interesses do capital estrangeiro. Nesse contexto, os movimentos sociais não poderiam se concentrar em lutas imediatas e pontuais, como a terra, o emprego e a moradia (JST, 1997, $\mathrm{n}^{\circ}$ 175, p. 11). Em seu planejamento, a mobilização popular deveria se dar pela articulação de lutas identificadas pelo enfrentamento ao "projeto das elites", tendo como foco "o combate às privatizações" e aos desmandos do mercado financeiro, “em defesa do emprego e da soberania nacional” (JST, 1997, n 175, p. 11). Para manter sua identidade sem desmerecer outras frentes de luta, o MST lançou apoio a diversos movimentos em defesa da democratização da mídia.

A partir do Consulta Popular colocou-se em pauta a formulação de um "Projeto Popular para o Brasil”. Nos debates preliminares, o controle da comunicação de massa foi questionado por militantes:

As elites estão nos derrotando no campo da comunicação de massa. Seja pelo grande monopólio, seja pela orientação ideológica que imprimem. Precisamos descobrir formas de multiplicar a comunicação de massa alternativa e mais unitária. Por exemplo: assumir o compromisso de multiplicar rádios e TV comunitárias; criar jornais mais unitários e melhor utilização dos espaços que já construímos; criar redes de cidadania, utilizar melhor a internet entre nós. (JST, 1997, nº 175, p. 11)

As projeções políticas do Consulta Popular, em parte, retrataram experiências de uso da mídia pelo MST que contribuíram para a conquista de espaço pelo movimento social no cenário político nacional e internacional. Isto decorreu da capacidade de organização de mobilizações e ocupações, da produção de meios de comunicação e dos embates travados com a grande imprensa. Acreditava-se que os meios de comunicação nas mãos de algumas famílias inviabilizavam o preceito democrático da liberdade de 
Em matéria publicada pelo Jornal Sem Terra, o jornalista e professor na Universidade de São Paulo (USP), Jair Borin, afirmou que o sistema de comunicação de massa no Brasil detinha um mercado que movimentava em publicidade 8,6 bilhões de dólares, como apontado pelo Grupo Meio \& Mensagem, especializado em informações e análises do mercado de comunicação. Os valores muito diziam o que orientava a pujança de interesses privados e empresariais nas questões políticas nacionais.

Embora a movimentação informada correspondesse a toda a mídia, para o jornalista "apenas uns 30 jornais diários, meia dúzia de revistas de grande porte e, principalmente, as seis redes privadas de televisão do país" eram os grandes logradores da "dinheirama”. A concentração de capital nos negócios publicitários, quando analisado o segmento das televisões, evidenciava uma situação pouco comum em outros países, correspondendo a 55\% do total da publicidade e tendo numa única empresa, a Rede Globo de Televisão, a fatura de $65 \%$ desse total (JST, 1998, n 182, p. 9). O domínio exercido pela Rede Globo no segmento das televisões fazia tudo girar "em torno do consumo de massa e do descompromisso com as lutas sociais da imensa maioria da população". O entretenimento difundia a representação de "ilha de tranquilidade" da sociedade brasileira, semelhante ao que se divulgava na ditadura militar (JST, 1998, n 182, p. 9).

Ainda, para Borin, a fórmula da Globo para manter a audiência do grande público consistia na manutenção de quatro novelas nos horários nobres e de três noticiários pautados no que denominou "show business". Para o jornalista, a notícia, ao ser tratada pelos jornais televisivos como "espetáculo de curiosidades, amenidades e fofocas" fizeram escola no Brasil e foram reproduzidas por outros canais concorrentes, além de ser praticado, com versões glamourizadas, na maior revista semanal do país, a Veja.

Estratégias de comunicação que focalizaram as propostas e agendas políticas do governo de Fernando Henrique Cardoso (FHC) e contribuíram para a configuração de um ambiente de consumo de massa e de descompromisso com as lutas sociais foram percebidas pelo jornalista e professor da Pontifícia Universidade Católica de São Paulo 

para jornais de ampla circulação. A análise do jornalista também era direcionada à Rede Globo, considerada uma empresa que dominava o imaginário brasileiro, interferia diretamente nas questões políticas nacionais e adotava um padrão de ideias que deixava claro seu vínculo com o período autoritário em que foi criada (JST, 1999, n 193, p. 4).

Para Arbex Jr., embora num regime dito democrático, o Brasil enfrentava uma ditadura da imprensa. Em meio à homogeneização da pauta dos grandes meios de comunicação decorrente das agências de notícias, quando os movimentos sociais ganhavam visibilidade eram retratados por um viés de marginalização e contravenção aos interesses econômicos do setor privado. O mesmo não se verificava quando forças repressivas do Estado atuavam com violência contra trabalhadores rurais sem-terra, predominando justificativas às ações policiais ou pairando o silêncio, como se nada tivesse acontecido.

O jornalista questionou o significado da liberdade de expressão com uma imprensa seletiva e parcial ao afirmar que:

Existe certo temor quando se comenta a imprensa, porque parece que a imprensa é democrática. A imprensa mente! A imprensa é mentirosa. Então, para falar desse Brasil que não existe, a imprensa mente diariamente sobre o Brasil. O exemplo que eu posso dar, um exemplo pessoal, é a reportagem que fizemos com a revista Caros Amigos, no Paraná. Não é possível. O que estava acontecendo no Paraná e não tinha ninguém sabendo. Eu fui lá e vi. Mas, pela imprensa, jamais eu ficaria sabendo alguma coisa porque a imprensa não divulga. Será que a imprensa não sabe? É claro que a imprensa sabe. A imprensa mente. (JST, $1999, n^{\circ} 193$, p. 5)

A indignação do jornalista se referia à cobertura que fez da ação violenta da Polícia Militar para desalojar centenas de famílias acampadas em fazendas do município de Querência do Norte e da região noroeste do Paraná, em maio de 1999. A reportagem, intitulada "Terror no Paraná", foi publicada pela Caros Amigos e conquistou o Prêmio Vladimir Herzog de Anistia e Direitos Humanos, categoria Revista, naquele ano. 
O receio de criticar a imprensa estava no combate dado pela grande mídia a grupos políticos ou setores populares que propusessem o controle público ou o controle social dos meios de comunicação. A retórica usada pelos empresários de mídia, em resposta a qualquer manifestação que apontasse uma proposta regulatória, era motivo para se produzir um efeito de notícias de que a liberdade de expressão estava sendo atingida e o retorno da ditadura militar era iminente. Ou seja, no decorrer dos anos, parece que projetos que apontaram para a responsabilização da imprensa frente a erros e injustiças cometidos contra cidadãos, bem como, para organizações coletivas em defesa da democratização da mídia, foram considerados, por grandes grupos de comunicação, ações de cerceamento da liberdade de expressão que comprometiam a democracia brasileira ao trazer à tona práticas próprias de ditaduras militares.

A concentração de poder se refletia no tratamento dado pela mídia comercial aos movimentos sociais. O editor da revista Caros Amigos, Sérgio de Souza, em entrevista ao Jornal Sem Terra, explicou por que meios de comunicação de grande circulação insistiam em massacrar o MST. Para ele, a imprensa brasileira era:

(...) um dumping antipopular, cujos integrantes estão mais interessados em faturar do que em informar e formar. Um bando de empresários totalmente devotados ao governo, defensores ferrenhos do modelo econômico imposto pelo FMI e dessa globalização que vem globalizando tudo, menos os pobres, quer dizer, a maioria esmagadora da população. Um exemplo simples: quando o Estadão, em editorial (...) de elogio a um discurso de FHC se declarou preocupado em "reduzir a pobreza a níveis mais toleráveis", tem-se a dimensão do ideário da imprensa rica do Brasil. (JST, 2000, $\mathrm{n}^{\circ}$ 201, p. 4)

As observações sobre a atuação da grande imprensa no cenário político nacional e o alinhamento dos empresários das comunicações com o governo FHC era um dos incômodos dos movimentos sociais. No caso do MST, a tensão se ampliava diante das reportagens que eram divulgadas sobre os trabalhadores rurais sem-terra. Para lideranças, a mídia estava a serviço do Palácio do Planalto ao contribuir para a produção e divulgação de notícias que, de maneira explícita ou nas entrelinhas, contribuíam para a marginalização e criminalização do movimento social perante a opinião pública. 
Nesse sentido, era necessário produzir táticas para enfrentar as estratégias de grupos econômicos e políticos na expansão do neoliberalismo (BOURDIEU, 1998). Uma das alternativas estava na mobilização a favor da democratização da mídia, no embate aos meios de comunicação contrários aos movimentos sociais e na desmistificação de imagens de lideranças populares produzidas pela grande mídia.

Nas redes de televisão, nas revistas semanais e nos jornais impressos diários, muitas eram as semelhanças de expressões e discursos utilizados para atacar as mobilizações populares e, mais especificamente, o MST. Dentre tantos embates, o que chamou atenção foi o travado entre a direção nacional do MST e a revista Veja. As críticas feitas pelo MST tomaram como referência a capa da revista de junho de 1998, que expôs a imagem de João Pedro Stédile e a manchete "A esquerda com raiva”. As observações da Revista Sem Terra sobre as publicações do semanário pautaram-se no princípio da "demonização do MST", caracterizada por reportagens que explicitaram as ações do movimento social por uma "face violenta". As expressões pejorativas usadas pela Veja para descrever os sem-terra como "desempregados, analfabetos, agricultores arruinados, comerciários sem eira nem beira, gente que foi boia-fria, veio da favela nas grandes cidades e massa de pés-descalços", relacionaram a cor vermelha com "bandeira arcaica" e trataram os objetivos do MST como "assunto do século passado, fora de moda, insepulto" (SOUZA, 2004: 58).

Para Borin, o negócio que envolvia a Veja, além de refletido nos produtos divulgados em sofisticadas propagandas, despertava o interesse de grandes empresários mundiais da comunicação de massa, atraindo a Globo para a disputa deste segmento jornalístico com o lançamento da revista Época. Diante do quadro, a análise simplista de que o movimento social de luta pela terra era prejudicado e "demonizado" pelas grandes revistas de circulação semanal não deveria preponderar sob a nua reflexão de que, por motivos econômicos óbvios e por suas concepções de sociedade,o MST nunca seria tratado de maneira positiva por estas revistas, cabendo "um forte movimento de massas" para "reverter o controle que a mídia" exercia "sobre a informação no Brasil" (JST, 1998, nº182, p. 9). 
A “satanização do MST” pela revista Veja (SOUZA, 2004), pela Rede Globo e pelo jornal O Estado de S. Paulo foi considerada como uma prática jornalística tão óbvia que não necessitava de análise mais densa. O que preocupava o jornalista era a "engenharia de consenso" através de narrativas que, além de dificultarem a suspeição das notícias, justificavam métodos ditatoriais de um governo dito como democrático. Foi o caso do emprego pela Folha de S. Paulo da palavra "invasão" para se referir às ocupações de prédios públicos em doze estados. Considerado conservador pelo movimento social, o termo passou a ser entendido como "acusação gravíssima" quando transformado em "atentado" nas páginas do jornal paulista.

O alinhamento entre imprensa e governo federal em apoio ao neoliberalismo e à globalização contrapunha-se às posições de movimentos sociais. Como termômetro do que leitores percebiam nas relações de forças políticas, a seção Cartas do Jornal Sem Terra divulgou correspondências de várias regiões do Brasil. Numa delas, o descontentamento de uma leitora retratou um pouco do que se entendia como articulação entre a mídia e o Palácio do Planalto. Para ela, existia uma "democracia de fachada" que oprimia setores populares da sociedade brasileira. Assim, manifestou apoio à luta pela reforma agrária e justiça, repudiou "a violência e a repressão com que o governo FHC" vinha tratando "a legítima mobilização dos sem-terra", rechaçou "a censura da TVE por retirar do ar a entrevista do João Pedro Stédile" e a "matéria da capa da revista Veja número 1.648" (JST, 2000, n²01, p. 23), que estampou a bandeira do MST com a manchete "A tática da baderna: o MST usa o pretexto da reforma agrária para pregar a revolução socialista" (VEJA, $\left.n^{\circ} 1.648,15 / 05 / 2000\right)$.

Atrás da seletividade e do que era sintetizado em cartas de leitores estava um amplo conjunto de denúncias contra o governo por censurar e manipular informações sobre o MST, numa nebulosa aproximação com a grande mídia. As ocorrências já eram publicadas em diversos meios de comunicação através de editoriais, entrevistas, colunas e veículos de observação da imprensa. No centro da polêmica estava a interferência do secretário de Comunicação da Presidência da República, Andrea Matarazzo, no veto da entrevista de João Pedro Stédile na TVE (FILHO, 2006, p. 47) e a denúncia de seu envolvimento com a produção e a publicação da matéria sobre o MST na revista Veja 
características de making off da capa do semanário, que demonstrava estreitas relações do secretário de governo com a revista (JST, 2000, n² 200, p. 13).

Este caso retrata os "óculos especiais" dos jornalistas, que "veem certas coisas, e não outras" (BOURDIEU, 1997). No governo FHC, adotou-se uma estratégia de isolamento do MST em que se utilizou a imprensa para difundir acusações contra trabalhadores rurais sem-terra. Como forma de embate ao que jornalistas engajados consideravam as "forças obscuras do autoritarismo" apoiadas por meios de comunicação de massa, o movimento social intensificou mobilizações e ocupações (JST, 2000, n² 201, p. 5).

Muito mais do que um movimento social pela reforma agrária, o MST atingiu interesses econômicos dos meios de comunicação de massa. Além da desapropriação de terras e da manutenção de assentamentos rurais, a democratização da comunicação foi debatida pelo movimento social e demonstrou que o jogo político dependia da capacidade de mobilização de grupos econômicos e sociais na produção, divulgação e recepção de ideias.

As estratégias de comunicação adotadas pelo MST delinearam uma dinâmica simbólica que fez da luta pela reforma agrária uma luta pela produção da notícia. Como resultado, a elaboração de impressos e o embate entre MST e mídia integraram a formação e consolidação do movimento social que, no decorrer dos anos, construiu uma política de comunicação como parte de sua estrutura. Este debate evidenciou na luta dos trabalhadores rurais sem-terra o quanto o direito à comunicação pode representar a manutenção de práticas autoritárias ou o avanço das relações democráticas. 


\section{Considerações finais}

Nas décadas de 1980 e 1990, o Movimento dos Trabalhadores Rurais Sem Terra (MST) produziu meios de comunicação para informar militantes e simpatizantes da luta pela reforma agrária. As concepções de imprensa, meios de comunicação de massa e mídia circularam na militância e demonstraram um amadurecimento do movimento social na configuração de um campo de comunicação. De um lado, o MST serviu de modelo para outros movimentos sociais que desenvolveram projetos de comunicação populares e alternativos em contraposição à grande mídia. De outro, antes delimitador da imprensa como inimiga, o MST construiu uma política que permitiu compreender a complexa relação de poderes que envolvem as comunicações, considerando as múltiplas relações que não se restringem a abordagens maniqueístas, embora estas sejam condições de afirmação e sobrevivência de grupos sociais e políticos.

Neste processo, ao definir os meios de comunicação de massa como um conjunto de impressos, empresas de televisão e rádio com finalidades econômicas e comerciais que se distanciavam dos anseios políticos do movimento social, as experiências comunicativas do MST possibilitaram sua inserção nas complexas relações que permeiam o campo midiático, seja se alinhando a projetos alternativos de comunicação, seja se opondo aos interesses dos conglomerados de mídia, numa tensão em que se definiam interesses sociais, públicos e privados nas comunicações.

O olhar de Vito Gianotti, ao escrever "o que era simples imprensa virou mídia”, alguns anos distantes do período delimitado por este texto, alcançou a complexidade para se pensar a política em sociedades cada vez mais descentradas pelas tecnologias de comunicação. Na organização do MST, as mudanças ocorreram em fronteiras complexas entre o espaço público e o espaço de visibilidade midiática. O aprofundamento democrático defendido pelo movimento social contribuiu para a militância perceber a função ocupada pelos meios de comunicação do MST e os meios de comunicação de massa, como também, compreender as inúmeras formas de circulação e recepção de notícias sobre o MST produzidas pela grande mídia. Assim, para manter sua identidade sem desmerecer a importância de outras frentes de luta, além de estabelecer parâmetros 
Por fim, as dificuldades de veiculação das reivindicações dos sem-terra em canais de comunicação comerciais criaram condições políticas no MST para a elaboração e apropriação de meios de comunicação que contribuíram, em muito, para a construção de uma memória do movimento social de luta pela terra no Brasil. Ao acessar um material extenso de boletins, jornais e revistas, é possível compreender como o MST se posicionou perante questões importantes para a consolidação da democracia brasileira, o que não o reduz a uma organização à margem dos grandes meios de comunicação.

\section{Referências}

ALDÉ, Alessandra. A construção da política: democracia, cidadania e meios de comunicação de massa. Rio de janeiro: FGV, 2004.

BACZKO, Bronislaw. Les imaginaires sociaux. Paris: Payot, 1984.

BERGER, Christa. Campos em confronto: a terra e o texto. Porto Alegre: UFRGS, 1998.

BERTOL, Raquel. Como os sem-terra se inventaram pela mídia: a novidade social nos anos 1990. Estudos Históricos, Rio de Janeiro, v. 1, n. 31, 2003.

BOURDIEU, Pierre. A economia das trocas simbólicas. $5^{\mathrm{a}}$ ed. São Paulo: Perspectiva, 2001.BST. Porto Alegre: MJDH/CPT/PU, nº 4, 1981.

BST. Porto Alegre: Regional Sul, $n^{\circ} 33,1983$.

BST. Porto Alegre: Regional Sul, $n^{\circ}$ 35, 1984.

CHARTIER, Roger. A história cultural: entre práticas e representações. $2^{\mathrm{a}}$ ed. Lisboa: Difel, 2002.

CORREIA, João Carlos. Novos movimentos sociais e transformações no modelo de análise das mídias. In: FERREIRA, Jairo; VIZER, Eduardo (Orgs.). Mídia e movimentos sociais: linguagens e coletivos em ação. São Paulo: Paulus, 2007. 
FILHO, Laurindo Lalo Leal. A TV sob controle: a resposta da sociedade ao poder da televisão. São Paulo: Summus, 2006.

HOBSBAWM, Eric; RANGER, Terence. A invenção das tradições. Rio de Janeiro: Paz e Terra, 1997.

JST. São Paulo: MST, nº 55, 1985.

JST. São Paulo: MST, nº 61, 1987.

JST. São Paulo: MST, nº 67, 1987.

JST. São Paulo: MST, nº 160, 1996.

JST. São Paulo: MST, nº 164, 1996.

JST. São Paulo: MST, nº 175, 1997.

JST. São Paulo: MST, nº 182, 1998.

JST. São Paulo: MST, nº 193, 1999.

JST. São Paulo: MST, n² 200, 2000.

JST. São Paulo: MST, n² 201, 2000.

JST. São Paulo: MST, nº 262, 2006.

MARTIN-BARBERO, Jesus. Dos meios às mediações: comunicação, cultura e hegemonia. $7^{\text {a }}$ ed. Rio de Janeiro: UFRJ, 2015.

MARTIN-BARBERO, Jesus. Ofício de cartógrafo: travessias latino-americanas da comunicação na cultura. São Paulo: Loyola, 2004.

MORISSAWA, Mitsue. A história da luta pela terra e o MST. São Paulo: Expressão Popular, 2001.

MST, Carta aos Companheiros Jornalistas e Fotógrafos. São Paulo: MST, 1996.

MST, Por uma política de comunicação. São Paulo: MST, 1995. 
PERUZZO, Maria Cicília Krohling.et al..
redes? São Leopoldo: Unisinos, 2002.

PORTO, Mauro P. Televisão e política no Brasil: a Rede Globo e as interpretações da audiência. Rio de Janeiro: E-papers, 2007.

RST. São Paulo: Anca, nº 3, 1998.

WILLIAM, Raymond. Televisão: tecnologia e forma cultural. São Paulo: Boitempo; Belo Horizonte: PUCMinas, 2016.

SILVA, José Gomes da. Buraco negro: a reforma agrária na Constituinte. Petrópolis: Paz e Terra, 1989.

SIRINELLI, Jean François. Os intelectuais. In: RÉMOND, René (Org.). Por uma história política. Rio de Janeiro: FGV, 1996.

SOUZA, Eduardo Ferreira de. Do silêncio à satanização: o discurso de Veja e o MST. São Paulo: Annablume, 2004.

TEORIA E DEBATE. São Paulo: PT, nº. 18, 1992.

VEJA. São Paulo: Abril, nº 1648,15/05/2000.

Recebido em 30/04/2017 Aprovado em 09/08/2017

Universidade do Estado de Santa Catarina - UDESC Programa de Pós-Graduação em História - PPGH

Revista Tempo e Argumento Volume 09 - Número 21 - Ano 2017 tempoeargumento@gmail.com 